\title{
3: $95821-98085$
}

National Cancer Institute

\section{Source}

National Cancer Institute. 3: 95821-98085. NCI Thesaurus. Code C41893.

Physical location of CCRL2_Gene 